\title{
PENGEMBANGAN KURIKULUM PENDIDIKAN AGAMA DALAM MENCIPTAKAN SIKAP TOLERANSI BERAGAMA DI MADRASAH ALIYAH DAN SEKOLAH MENEGAH ATAS KABUPATEN BANGKA
}

\author{
Soleha \\ IAIN Syaikh Abdurrahman Siddik Bangka Belitung, Indonesia \\ soleha215x@gmail.com
}

\begin{abstract}
Abstrak: Penelitian ini bertujuan untuk mengetahui Pengembangan Kurikulum Pendidikan Agama dalam menciptakan sikap toleransi beragama di Madrasah Aliyah dan Sekolah Menegah Atas Kabupaten Bangka. Pengembangan kurikulum dalam materi pendidikan agama baik di sekolah dan madrasah, terkait dengan toleransi, memberikan pemahaman dan wawasan kepada peserta didik akan pentingnya memahami perbedaan antar agama ataupun sesama agama. Hasil penelitian ini menjelaskan bahwa pengembangan kurikulum pendidikan agama di sekolah dan madrasah sangat perlu dilakukan untuk menjawab permasalahan kondisi saat ini terkait dengan toleransi beragama. Khususnya di sekolah yang memiliki beragam agama, etnis dan budaya, sehingga sikap toleransi harus dibangun salah satunya melalui penyampaian materi agama dan diaplikasikan di lingkungan sekolah dan masyarakat. Sikap toleransi beragama yang ada di SMA maupun Madrasah Aliyah, baik sesama agama ataupun antar agama terjalin secara aktif dan dinamis.
\end{abstract}

Kata Kunci: Pengembangan Kurikulum, Pendidikan Agama, Toleransi Beragama 
Pengembangan Kurikulum Pendidikan Agama dalam Menciptakan Sikap Toleransi Beragama di Madrasah Aliyah dan Sekolah Menegah Atas Kabupaten Bangka

\section{A. Pendahuluan}

Pendidikan agama dan pendidikan keagamaan semakin menguat, bukan hanya sebagai legalitas eksistensi kelembagaan, juga penyelenggaraannya dan tanggung jawab akademis, sehingga ketentuan-ketentuan pengelolaan lembaga pendidikan umum dan atau kejuruan jenjang dasar dan menengah juga berlaku pada madrasah dan pesantren. Salah satu ketentuan strategis dalam penyelenggaraannya adalah kurikulum.

Kurikulum sebagai salah satu komponen terpenting yang telah banyak memberikan kontribusi dalam proses pembelajaran baik di lembaga pendidikan formal maupun non formal. Dimana pengembangan kurikulum merupakan proses dinamika dari tuntutan perubahan struktur pemerintah maupun globalisasi. Oleh sebab itu, Oemar Hamalik menyebutkan kebijakan umum dalam pengembangan kurikulum harus sejalan dengan visi, misi, dan strategis pembangunan pendidikan nasional yang dituangkan dalam kebijakan peningkatan angka partisipasi, mutu, relevansi, dan efesiensi pendidikan. Yang salah satu prinsipnya mengacu kepada keseimbangan etika, logika, estetika, kinestetika, dan pendidikan multikultural. ${ }^{1}$

Pendidikan multikultural sebagai salah satu prinsip yang diungkapkan di atas, memiliki alasan yang kuat untuk dibahas. Sebagai bangsa yang besar, Indonesia merupakan masyarakat majemuk, interaksi antar umat beragama menjadi sebuah keniscayaan yang tidak bisa dihindari. Menurut Nunu Ahmad dan an-Nahidl, masyarakat Indonesia yang dikenal religius memiliki keramahan, tidak immune dari potensi konflik bermotifkan agama sudah sering terjadi, baik antar umat beragama maupun antar agama. ${ }^{2}$

Berdasarkan data survey terbaru dari Pusat Pengkajian Islam dan Masyarakat (PPIM) UIN Jakarta, menemukan bahwa mayoritas guru beragama Islam di Indonesia memiliki opini intoleran dan radikal yang tinggi. Saiful Umam selaku Direktur Eksekutif PPIM UIN Jakarta menyebutkan "Guru di Indonesia dari TK/RA hingga SMA/MA memiliki opini intoleran dan opini radikal yang tinggi”. Dengan sampel

\footnotetext{
${ }^{1}$ Lihat Oemar Hamalik, Manajemen Pengembangan Kurikulum, cet ke 5 (Bandung: Remaja Rosdakarya, 2012), hlm.3-4.

${ }^{2}$ Nunu Ahmad dan An-Nahidl dkk, Pendidikan Agama di Indonesia: Gagasan dan Realitas (Jakarta: Puslitbang Pendidikan Agama dan Keagamaan Badan Litbang dan Diklat Kementerian Agama RI, 2010), hlm. 259-260.
} 
2.237 guru muslim terdiri dari guru TK/RA, MI/SD, SMP/MTS, SMA/MA di Indonesia. Dari jumlah tersebut ditemukan sebanyak 10,01\% guru Muslim punya opini sangat intoleran secara implisit dan 53,06\%, memiliki opini yang intoleran secara implisit. Selain itu, 6,03\% guru Muslim memiliki opini sangat intoleran dan 50,87\% guru memiliki opini intoleran secara eksplisit. Lebih lanjut, dari hasil penelitian PPIM, ada tiga faktor yang menyebabkan seseorang terpapar intoleran dan radikalisme, yaitu faktor pandangan Islamis, demografis, serta keterlibatan dengan ormas dan sumber pengetahuan ke-Islaman. ${ }^{3}$

Melihat dari permasalahan di atas, ada hal yang mendasar harus di pahami seorang guru tentang toleransi beragaman dalam proses pembelajaran berlangsung. Mengingat rumusan yang dikeluarkan oleh Kemendiknas, ada 18 nilai karakter bangsa Indonesia yang harus dilaksanakan dalam proses pembelajran, diantaranya adalah toleransi. ${ }^{4}$

Berkaitan dengan hal tersebut, pendidikan seharusnya berperan aktif dalam memberikan penyadaran akan pentingnya keberagaman untuk menciptakan harmonisasi dalam kehidupan khususnya di lembaga pendidikan. Sehingga, proses humanisasi dan kerukunan dalam lingkungan keluarga, masyarakat bisa tercipta dengan baik. Oleh sebab itu, aspek kurikulum yang tertuang dari pendidikan agama harus memberikan pemahaman yang jelas tentang perbedaan ini. Sehingga terhindar dari perselisihan di lembaga pendidikan dan terciptanya sikap toleransi beragama antar siswa. Salah satu upaya strategis yang bisa dilaksanakan untuk membangun generasi yang sadar budaya, dengan menanamkan nilai keberagaman di lembaga pendidikan, dapat dikembangkan dalam kurikulum pendidikan agama. Sehingga diharapkan, praktik pendidikan diarahkan pada sebuah pencapaian tujuan-tujuan tertentu, baik berkenaan dengan penguasaan pengetahuan, pengembangan pribadi, kemampuan sosial, ataupun kemampuan skill.

\footnotetext{
${ }^{3}$ Lihat https:/ /www.cnnindonesia.com/nasional/20181018153237-20-339600/survei-guru-muslimpunya-opini-intoleran-dan-radikal-tinggi.

${ }^{4}$ Kemendiknas, Bahan pelatihan Penguatan Metodologi Pembelajaran Berdasarkan Nilai-Nilai Budaya untuk Membentuk. Daya Saing dan Karakter Bangsa (Jakarta: Kementerian Pendidikan Nasional Badan Penelitian dan Pengembangan Pusat Kurikulum, 2010), hlm. 9-10.
} 
Pengembangan Kurikulum Pendidikan Agama dalam Menciptakan Sikap Toleransi Beragama di Madrasah Aliyah dan Sekolah Menegah Atas Kabupaten Bangka

Bangka Belitung sebagai provinsi kepulauan memiliki keberagaman etnis, agama dan budaya. Salah satu yang sangat mencolok adalah menyatunya etnis Cina dan Melayu dalam interaksi sosial mereka. Fenomena keberagaman yang telah terbentuk sejak lama, menurut Irwan Abdullah karena adanya pengaruh agama Hindu dan Budha yang lebih awal dianut oleh sebagian masyarakat. Keberagaman budaya Indonesia mencakup bahasa, agama dan kurang lebih 500 suku bangsa menyatu di bawah Bhineka Tunggal Ika yang dipraktikkan pada tingkat lokal. ${ }^{5}$

Kondisi ini juga terjadi di lembaga pendidikan, dari SD sampai SMA. Peserta didiknya terdiri beberapa etnis khususnya di kabupaten Bangka antara lain SMAN 1, SMKN 1, SMK Yapensu dan SMA Setia Budi. Dimana peserta didik memiliki kebebasan untuk mengikuti pelajaran agama yang mereka anut. Menurut Fadhilah Imam, ${ }^{6}$ kebebasan tersebut mengacu pada kepentingan dan tuntutan masyarakat sebagai sekolah yang berwawasan kebangsaan.

Namun dari keberagaman tersebut, tidak menjadikan hubungan mereka di lingkungan sekolah menjadi terkotak-kotak. Berdasarkan latar belakang yang diungkapkan di atas, maka peneliti merasa perlu untuk melakukan suatu penelitian lebih lanjut tentang Pengembangan Kurikulum Pendidikan Agama dalam Menciptakan Sikap Toleransi Beragama di Madrasah Aliyah dan Sekolah Menegah Atas Kabupaten Bangka.

Kompleksitas permasalahan yang diidentifikasi terkait dengan pengembangan Kurikulum di Indonesia, khususnya dalam materi Pendidikan Agama di Madrasah Aliyah dan Sekolah Menengah Atas dalam menciptakan Sikap Toleransi Beragama antar siswa di lembaga pendidikan tersebut muncul karena keberagaman budaya, khususnya agama. Permasalahan yang diidentifikasi memunculkan pelbagai problematika idealisme dan ideologis. Pertanyaan-pertanyaan yang muncul mengenai perbedaan terutama berkenaan dengan "agama" yang dianut oleh peserta didik. Kemudian dengan pemberian materi pendidikan agama dan pelaksanaan

\footnotetext{
${ }^{5}$ Irwan Abdullah, Konstruksi dan Reproduksi Kebudayaan (Yogyakarta: Pustaka Pelajar, 2009), hlm. 64.

${ }^{6}$ Fadhilah Imam, SMA Setia Budi Sungailiat 40 Tabun di tengah Dinamika Pendidikan Nasional (Pangkalpinang: CV. Sumber Sarana Prima 2015), hlm. 46.
} 
"keagamaan" di Madrasah Aliyah dan Sekolah Menengah Atas khususnya di Kabupaten Bangka.

Dari pemaparan latar belakang di atas, maka rumusan masalah yang akan diangkat adalah: 1) Bagaimana Pengembangan Kurikulum Pendidikan Agama di Madrasah Aliyah dan Sekolah Menengah Atas Kabupaten Bangka? 2) Bagaimana Menciptakan Sikap Toleransi Beragama di Madrasah Aliyah dan Sekolah Menengah Atas Kabupaten Bangka?

Adapun tujuan penelitian ini adalah: 1) Untuk mengetahui Pengembangan Kurikulum Pendidikan Agama di Madrasah Aliyah dan Sekolah Menengah Atas Kabupaten Bangka; 2) Untuk mengetahui proses dalam Menciptakan Sikap Toleransi Beragama di Madrasah Aliyah dan Sekolah Menengah Atas Kabupaten Bangka.

Penulis melakukan literature review mengenai pengembangan kurikulum Pendidikan Agama kaitannya dengan Sikap Toleransi Beragama, ada beberapa penelitian yang sudah dilakukan antara lain: Sabil Mokodenseho dengan judul Toleransi Beragama dan Pembelajaran Agama Islam: Harmoni Masyarakat Minoritas Muslim Menado dengan hasil menyatakan bahwa, peran pemerintah belum tepat menangani konflik yang terjadi di Indonesia baik menggunakan pendekatan politik ataupun hukum karena sifatnya parsial. Oleh sebab itu, pendidikan agama merupakan salah satu solusi yang tepat untuk mengurai konflik-konflik yang berkepanjangan berkat peranannya sebagai social-reconstruction. ${ }^{7}$

Tesis yang ditulis oleh Maryam, tentang Penanaman Sikap Toleransi Siswa dalam Kehidupan Beragama di Sekolah Melalui Pendidikan Multikultural (Studi Kasus di SMA Setia Budi Sungailiat Kabupaten Bangka). Proses penanaman sikap toleransi beragama pada siswa dilakukan melalui: kebijakan sekolah, pembiasaan, kegiatan spontan, pengintegrasian nilai toleransi ke dalam mata pelajaran, dan kegiatan ekstrakulikuler. Sedangkan pelaksanaan pendidikan multikultural dengan mengidentifikasikan keberagaman siswa dengan menggabungkan dalam satu ruang kelas, serta memperbanyak kegiatan ekstrakulikuler. Sehingga secara umum dapat

\footnotetext{
${ }^{7}$ Sabil Mokodenseho, Toleransi Beragama dan Pembelajaran Agama Islam: Harmoni Masyarakat Minoritas Muslim Manado, Proseding Seminar Nasional dan Temu Ilmiah Jaringan Peneliti IAI Darussalam Blokagung Banyuwangi, https://www.researchgate.net/publication/321866877, diakses tanggal 12-09-2018.
} 
Pengembangan Kurikulum Pendidikan Agama dalam Menciptakan Sikap Toleransi Beragama di Madrasah Aliyah dan Sekolah Menegah Atas Kabupaten Bangka

disimpulkan bahwa, sikap toleransi beragama siswa Setia Budi sudah baik. Hal ini terlihat dari tidak terjadinya konflik dalam interaksi antar siswa yang berbeda agama, serta bekerja sama dan saling membantu antar sesama. ${ }^{8}$

Selanjutnya, penelitian yang dilakukan Tim Peneliti Balai Litbang Agama Makasar, Persepsi dan Sikap Siswa terhadap Tindak Kekerasan atas Nama Agama. Persepsi responden sangat positif dengan kata lain mereka tidak mentolelir aksi kekerasan baik dengan modus penyerangan kelompok/aliran sesat, penyerangan fisik terhadap oknum dan atau kelompok yang melakukan stigmatisasi ajaran agama. Sedangkan sikap yang ditunjukkan adalah positif, dengan tetap mengedepankan proses hukum walaupun menjadi viktim aksi kekerasan dengan modus pengerusakan rumah ibadah, stigmatisasi simbol-simbol agama, sebagai bagian dari upaya mencegah konflik menjadi eskalatif. Komitmen dan konsistensi dalam mengaktualisasikan ajaran agama yang diakses melalui institusi formal maupun kajian-kajian agama yang sarat dengan wawasan keagamaan yang inklusif dan moderat.

Perbedaan dengan penelitian yang akan dilakukan secara spesifik lebih menekankan pada pengembangan kurikulum pendidikan agama yang dilakukan di Madrasah Aliyah dan Sekolah Menengah Atas kabupaten Bangka, berkaitkan dengan Pengembangan Kurikulum yang tertuang dalam Materi Pembelajaran Pendidikan Agama yang dilakukan dalam proses pembelajaran di sekolah.

\section{B. Konsep Pengembangan Kurikulum}

Kurikulum berasal dari bahasa Latin, yang memiliki kata dasar "currere"secara harfiah berarti lapangan perlombaan lari. Sedangkan dalam setiap lapangan perlombaan pasti memiliki batas "start" dan batas "finish".' Sedangkan dalam bahasa Arab kurikulum diartikan dengan “manhaj” yaitu jalan yang terang atau jalan teran yang dilalui oleh manusia pada bidang kehidupannya. Dalam konteks pendidikan kurikulum berarti jalan terang yang dilalui pendidik dengan peserta didik untuk

\footnotetext{
${ }^{8}$ Maryam, Tesis: Penanaman Sikap Toleransi Siswa dalam Kehidupan Beragama di Sekolah melalui Pendidikan Multikultural (Studi Kasus di SMA Setia Budi Sungailiat Kabupaten Bangka), Program Pascasarjana IAINS Syaikh Abdurrahman Siddik Bangka Belitung, 2018.

${ }^{9}$ H. Muhaimin, Pengembangan Kurikulum Pendidikan Agama Islam di Sekolah, Madrasah dan PerguruanTinggi (Jakarta, PT. Raja Grafindo Persada, 2005), hlm, 1.
} 
mengembangkan pengetahuan, keterampilan dan sikap serta nilai-nilai. Selanjutnya Al-Khauly menjelaskan al-manhaj sebagai seperangkat rencana dan media untuk mengantarkan lembaga pendidikan dalam mewujudkan tujuan pendidikan yang di inginkan. ${ }^{10}$

Konsep kurikulum berkembang sejalan dengan perkembangan dengan teori dan praktik pendidikan, juga bervariasi sesuai dengan aliran atau teori pendidikan yang dianutnya. Ada tiga konsep kurikulum, kurikulum sebagai substansi, kurikulum sebagai sistem, dan kurikulum sebagai mata pelajaran. ${ }^{11}$

Konsep pertama, kurikulum sebagai substansi. Kurikulum dipandang sebagai suatu rencana kegiatan belajar mengajar bagi murid-murid di sekolah, atau suatu perangkat tujuan yang ingin dicapai. Konsep kedua, kurikulum sebagai sistem, yaitu sistem kurikulum. Sistem kurikulum merupakan bagian dari sistem persekolahan, sistem pendidikan, bahkan sistem masyarakat. Suatu sistem kurikulum mencakup struktur personalia dan prosedur kerja bagaimana cara menyusun kurikulum, melaksanakan, mengevaluasi, dan menyempurnakannya. Hasil dari suatu sistem kurikulum adalah tersusunnya kurikulum, dan fungsi dari sistem kurikulum adalah bagaimana memelihara kurikulum agar tetap dinamis. Konsep ketiga, kurikulum sebagai bidang studi yaitu bidang studi kurikulum. Yang merupakan bidang kajian para ahli kurikulum dan bidang ahli pendidikan dan pengajaran. Tujuan kurikulum sebagai bidang studi adalah mengembangkan ilmu tentang kurikulum dan sistem kurikulum. ${ }^{12}$

Oemar Hamalik menyebutkan, pengembangan kurikulum merupakan proses dinamika sehingga dapat merespons terhadap tuntutan perubahan struktural pemerintahan, perkembangan ilmu dan teknologi maupun globalisasi. Kebijakan umum dalam pengembangan kurikulum harus sejalan dengan visi, misi, dan strategis pembangunan pendidikan nasional yang dituangkan dalam kebijakan peningkatan angka partisipasi, mutu relevansi, dan efisiensi pendidikan. ${ }^{13}$

\footnotetext{
${ }^{10}$ H. Muhaimin, Pengembangan, hlm. 1.

${ }^{11}$ Nana Syaodhi Sukmadinata, Pengembangan kurikulum, Teori dan Praktik (Bandung: Remaja Rosdakarya, 2000), hlm, 27.

${ }^{12} \mathrm{Ibid}$, hlm. 27.

${ }^{13}$ Oemar Hamalik, Manajemen Pengembangan Kurikulum, cet. kelima (Bandung: Kerjasama Sekolah Pascasarjana Universitas Pendidikan Indonesia dengan PT. Remaja Rosdakarya, 2012), hlm. 3.
} 
Pengembangan Kurikulum Pendidikan Agama dalam Menciptakan Sikap Toleransi Beragama di Madrasah Aliyah dan Sekolah Menegah Atas Kabupaten Bangka

Jadi, pengembangan kurikulum adalah usaha yang dilakukan dalam mengembangkan proses pembelajaran sehingga tujuan pendidikan sesuai dengan perkembangan zaman baik secara substansi, sistem, dan kurikulum (bidang studi).

\section{Konsep Pendidikan Agama}

Undang-Undang Dasar 1945 Pasal 29 ayat (1) dan (2) mengamanatkan bahwa pendidikan agama memiliki kontribusi yang sangat penting dalam membangun kebhinekaan dan karakter bangsa Indonesia. Hal itu diperkuat oleh tujuan Pendidikan

Nasional yang tertuang dalam Undang-Undang Nomor 20 Tahun 2003 tentang Sistem Pendidikan Nasional, terutama pada penjelasan Pasal 37 Ayat (1) bahwa pendidikan agama dimaksudkan untuk membentuk peserta didik menjadi manusia yang beriman dan bertakwa kepada Tuhan Yang Maha Esa serta berakhlak mulia. Dengan demikian, pendidikan agama dapat menjadi perekat bangsa dan memberikan anugerah yang sebesar-sebesarnya bagi kemajuan dan kesejahteraan bangsa. Untuk mencapai cita-cita pendidikan tersebut, diperlukan pula pengembangan ketiga dimensi moralitas peserta didik secara terpadu, yaitu: moral knowing, moral feeling, dan moral action.

Pertama, moral knowing, meliputi: (1) moral awareness, kesadaran moral (kesadaran hati nurani). (2) Knowing moral values (pengetahuan nilai-nilai moral), (3) Perspective taking (kemampuan untuk memberi pandangan kepada orang lain, melihat situasi seperti apa adanya, membayangkan bagaimana seharusnya berpikir, bereaksi, dan merasakan). (4) Moral reasoning (pertimbangan moral) adalah pemahaman tentang apa yang dimaksud dengan bermoral dan mengapa kita harus bermoral. (5) Decision-making (pengambilan keputusan) adalah kemampuan mengambil keputusan dalam menghadapi masalahmasalah moral. (6) Self-knowledge (kemampuan untuk mengenal atau memahami diri sendiri), dan hal ini paling sulit untuk dicapai, tetapi hal ini perlu untuk pengembangan moral. $^{14}$

Kedua "moral feeling" (perasaan moral), yang meliputi enam aspek penting, yaitu (1) conscience (kata hati atau hati nurani), yang memiliki dua sisi, yakni sisi kognitif

\footnotetext{
${ }^{14}$ Thomas Lickona, Character Matters: Persoalan Karakter, Bagaimana Membantu Anak Mengembangkan Penilaian Yang Baik, Integritas dan Kebijakan Penting Lainnya (Jakarta: PT. Bumi Aksara, 2015).
} 
(pengetahuan tentang apa yang benar) dan sisi emosi (perasaan wajib berbuat kebenaran). (2) Self-esteem (harga diri). (3) Empatby (kemampuan untuk mengidentifikasi diri dengan orang lain, atau seolah-olah mengalami sendiri apa yang dialami oleh orang lain dan dilakukan orang lain). (4) Loving the good (cinta pada kebaikan); (5) Self-control (kemampuan untuk mengendalikan diri sendiri), dan berfungsi untuk mengekang kesenangan diri sendiri. (6) Humility (kerendahan hati). ${ }^{15}$

Ketiga, "moral action" (tindakan moral), terdapat tiga aspek penting, (1) competence (kompetensi moral), yaitu kemampuan untuk menggunakan pertimbanganpertimbangan moral dalam berperilaku moral yang efektif; (2) will (kemauan), yakni pilihan yang benar dalam situasi moral tertentu, biasanya merupakan hal yang sulit; (3) habit (kebiasaan), yakni suatu kebiasaan untuk bertindak secara baik dan benar. ${ }^{16}$

\section{Konsep Sikap Toleransi Beragama}

\section{Sikap}

Sikap dalam bahasa inggris yang disebut attitude. ${ }^{17}$ Menurut R. Sutarno sikap adalah pandangan atau perasaan yang disertai kecenderungan untuk bertindak terhadap objek tertentu. Yang juga diartikan sebagai keadaan dalam diri manusia untuk bertingkah laku ataupun bertindak terhadap objek tertentu. Dengan kata lain, suatu objek dapat memberi rangsangan yang dapat menimbulkan sikap pada diri seseorang. ${ }^{18}$

Sikap yang ditimbulkan seseorang dilandasi oleh beberapa faktor. W.A. Gerungan menyebutkan bahwa faktor-faktor yang memegang peranan terbentuknya atau berubahnya sikap antara lain: pertama, interaksi sosial di dalam kelompok dan di luar kelompok, kedua, Faktor pribadi manusia itu Internal di dalam diri manusia; yaitu selektivitasnya sendiri, daya pilihnya sendiri, minat perhatiannya untuk. Ketiga, Faktor eksternal; yakni sifat, isi pandangan baru yang ingin diberikan, siapa yang

\footnotetext{
${ }^{15}$ Ibid.

${ }^{16}$ Ibid.

${ }^{17}$ Kimberly Adams Kimberly \& A.A. Waskito, Kamus Inggris-Indonesia Indonesia-Inggris; Reguler Verb Irreguler Verb (Jakarta: PT. Wahyu Media, 2008), hlm. 529.

${ }^{18}$ Maswardi Muhammad Amin, Pendidikan karakter Anak Bangsa (Jakarta: Baduose Media, 2011), hlm. 59.
} 
Pengembangan Kurikulum Pendidikan Agama dalam Menciptakan Sikap Toleransi Beragama di Madrasah Aliyah dan Sekolah Menegah Atas Kabupaten Bangka

mengemukakan yang mendukung pandangan baru tersebut, dengan cara bagaimana pandangan itu diterangkan, dan dalam situasi bagaimana sikapitu diperbincangkan. ${ }^{19}$ Jadi sikap dapat dimaknai sebagai respon atau reaksi terhadap keadaan dalam diri seseorang yang berhubungan dengan cara pandang, pengamatan, perasaan, dan tindakan pada objek di luar dirinya, sehingga sikap yang ditimbulkan akan menjadi fokus.

\section{Toleransi Beragama}

Toleransi dalam bahasa Inggris, yaitu tolerance ${ }^{20}$ yang berarti sikap tenggang rasa. Dalam bahasa Arab disebut dengan Tasamub yang berarti saling mengizinkan, saling memudahkan. ${ }^{21}$ Sedangkan dalam Kamus besar Bahasa Indonesia, toleransi berarti sifat atau sikap toleran, batas waktu untuk penambahan atau pengurangan yang masih diperolehkan, penyimpangan yang masih dapat diterima di pengukuran kerja. ${ }^{22}$

Baidhawy mendeskripsikan bahwa toleransi adalah kesiapan dan kemampuan batin bersama orang lain yang berbeda secara hakiki meskipun terdapat konflik dengan pemahaman tentang yang baik dan jalan hidup yang layak. Lebih lanjut dijelaskan bahwa toleransi di sini bukanlah dalam bidang akidah Islamiyah, karena akidah telah digariskan secara tegas dalam al-Qur'an dan Hadits. ${ }^{23}$

Selanjutnya Budhy Munawar dan Rahman menjelaskan bahwa toleransi adalah bersifat atau bersikap menenggang (menghargai, membiarkan, membolehkan) pendirian (pendapat, pandangan, kepercayaan, kebiasaan, kelakuan dan sebagainya) yang berbeda atau bertentangan dengan pendirian sendiri, akan tetapi dalam Islam toleransi bukanlah bersikap pluralisme. ${ }^{24}$

\footnotetext{
${ }^{19}$ W.A. Gerungan, Psikologi Sosial, Ed.3, cet. Kesatu (Bandung: PT. Refika Aditama, 2004), hlm. 167168.

${ }^{20}$ Kimberly Adams Kimberly \& A.A. Waskito, Kamus Inggris-Indonesi, hlm. 263.

${ }^{21}$ Said Agil Husin Al-Munawar, Fikih Hubungan antar Agama, cet. ketiga (Ciputat: PT Ciputat Press, 2005), hlm.12. hlm. 1478

${ }^{22}$ Departemen Pendidikan Nasional, Kamus Besar Bahasa Indonesia Edisi Keempat (Jakarta: Balai Pustaka),

${ }^{23}$ Zakiyuddin Baidhawy, Pendidikan Agama Berwawasan Multikultural (Jakarta: PT: Gelora Aksara Pratama, 2005), hlm. 79.

${ }^{24}$ Budhy Munawar dan Rahman, Islam Pluralis “wacana Kesetaraan Kaum Beriman” (Jakarta: PT. Raja Grafindo Persada, 2004), hlm. 39.
} 
Said Agil menyebutkan toleransi memiliki dua sifat, yaitu toleransi statis dan toleransi dinamis. Toleransi statis adalah toleransi dingin yang tidak melahirkan kerja sama. Sehingga kerukunan antar umat beragama hanya dalam bentuk teoretis yang akan melahirkan toleransi semu yang bersifat hipokritis. Sedangkan toleransi dinamis adalah toleransi aktif dan akan melahirkan kerja sama antar umat beragama bukan dalam bentuk teoritis, tetapi sebagai refleksi dari keberagaman umat beragama sebagai satu bangsa. Oleh sebab itu, toleransi dalam pergaulan hidup beragama berpangkal dari penghayatan ajaran masing-masing. Bila toleransi dalam pergaulan hidup ditinggalkan, berarti kebenaran ajaran agama tidak dimanfaatkan sehingga pergaulan dipengaruhi oleh saling curiga dan berprasangka. Maka perwujudan toleransi dalam pergaulan hidup antar umat beragama direalisasikan dengan cara, pertama, setiap penganut agama mengakui eksistensi agama-agama lain dan menghormati segala hak asasi penganutnya. Kedua, dalam pergaulan bermasyarakat, setiap golongan umat beragama menampakkan sikap saling mengerti, menghormati, dan menghargai. ${ }^{25}$

Jadi dapat disimpulkan, toleransi beragama adalah sikap saling menghargai pendapat dan perbedaan serta mengakui kebebasan dan hak-hak beragama bagi setiap warga negara dalam memeluk agama dan menjalankan ibadahnya masing-masing. Hal ini dikarenakan tiap individu memiliki hak kebebasan untuk menyakini, memeluk agama (mempunyai akidah), dan melaksanakan penghormatan (menjalankan ibadah) sesuai dengan aturan masing-masing agama yang diyakininya, baik sesama agama ataupun berbeda agama.

\section{E. Pengembangan Kurikulum Pendidikan Agama dalam Menciptakan Sikap Toleransi Beragama Di Sekolah Mengengah Atas Kabupaten Bangka}

\section{Pengembangan Kurikulum di Sekolah}

Berdasarkan analisa dari hasil wawancara bahwa pengembangan kurikulum dilakukan sebagai dasar bagi sekolah untuk mengembangkan materi pelajaran, yang di koordinir oleh Waka Kurikulum dalam menentukan program yang akan dilaksanakan. Sejak berlakunya K13 sekolah melaksanakan program yang telah ditentukan untuk

\footnotetext{
${ }^{25}$ Said Agil Al-Munawar, Fiqih Hubungnan, hlm. 16-17.
} 
Pengembangan Kurikulum Pendidikan Agama dalam Menciptakan Sikap Toleransi Beragama di Madrasah Aliyah dan Sekolah Menegah Atas Kabupaten Bangka

pengembangan kurikulum. Untuk itu, diperlukan keluwesan dan kreativitas guru dalam mengembangkan kurikulum. Dalam hal ini, kepala sekolah memberikan kebebasan kepada guru dalam mengembangkan materi yang diberikan. Keaktifan dan kreativitas guru sangat diperlukan dalam mengembangkan materi sesuai dengan kondisi saat ini.

Cara pelaksanaan pengembangan kurikulum di SMAN.1 Sungailiat menurut Efri Rantos, ${ }^{26}$ sebagai sekolah rujukan yang dibiayai APBD dari tahun 2016 sampai 2018 telah melaksanakan kegiatan IHT (In House Training) agar guru trampil dalam persiapan proses pembelajran, faktualnya sesuai dengan kondisi anak. Untuk itu, kepala sekolah selalu memberi kesempatan dan dukungan kepada semua guru untuk melakukan pengembangan materi pelajaran yang akan diajarkannya. Melalui kegiatan IHT, para guru bisa melakukan hal tersebut, dengan cara menunjuk calon narasumber untuk memberikan materi kegiatan yang telah ditentukan baik dari pusat maupun daerah. Selanjutnya bisa mengirim salah satu guru sebagai peserta ke pusat, ataupun mengirim para guru melalui kegiatan MGMP.

Pelaksanaannya pengembangan kurikulum di SMAN.1 Sungailiat dan Belinyu, secara keseluruhan tidak ada hambatan yang sangat mendasar. Kegiatan ini didukungnya; pertama, ketersediaan dana dari provinsi, melalui kegitan IHT yang didukung dari pemerintah daerah (APBD) memudahkan pihak sekolah dalam pelaksanaan pengembangan kurikulum. Kedua, tuntutan zaman, dimana para guru harus dapat mengembangkan diri demi kemajuan sekolah. Ketiga, ada dukungan yang kuat dari sekolah, kepala sekolah sebagai pengambil kebijakan, memberikan kemudahan kepada para guru dalam mengembangkan materi pelajaran. Maka diberikan kesempatan dan porsi yang sama kepada para guru untuk mengikuti kegiatan baik yang dilakukan ditingkat daerah maupun pusat.

Namun, untuk SMA Setia Budi sebagai sekolah swasta menjadi salah satu hambatan bagi guru SMA Setia Budi. Karena yang diutamakan untuk mengikuti kegiatan tersebut adalah guru-guru dari sekolah Negeri. Namun, ketika kesempatan

\footnotetext{
${ }^{26}$ Wawancara, Efri Rantos kepala Sekolah SMAN.1 Sungailiat.
} 
itu belum terpenuhi maka para guru harus lebih kreatif dengan banyak berkoordinasi dan berdiskusi sesama guru mata pelajaran melalui forum MGMP.

\section{Pelaksanaan Pendidikan Agama di SMA}

Untuk mengetahui pelaksanaan pendidikan Agama di SMA maka dilakukan wawancara kepada masing-masing kepala sekolah dan guru agama Islam, Budha, Katolik dan Protestan. Berdasarkan analisa dari hasil wawancara baik di SMAN.1 Sungailiat dan Belinyu pelaksanaan pendidikan agama sesuai dengan ketentuan yang telah berlaku. Untuk SMAN.1 Sungailiat, di awali dengan menunjuk wali kelas beragama Islam. Kebijakan ini dilakukan untuk menunjang kegiatan literasi sekolah dengan membaca ayat suci al-Qur'an selama 15 menit sebelum memulai kegiatan belajar mengajar, bukan sebagai diskriminasi dengan guru yang beragama lain. Sedangkan pelaksanaan pendidikan agama disesuaikan dengan agama yang dianut oleh siswa. Namun, bagi siswa selain muslim (Konghucu) dipersilahkan untuk mengikuti pelajaran agama lain. Karena dalam pembelajaran tersebut hanya memberikan tentang materi yang akan disampaikan, bukan untuk merubah keyakinan siswa.

Seyogianya materi pendidikan agama diberikan kepada peserta didik berdasarkan agama yang mereka anut masing-masing. Namun, keterbatasan gurudan jumlah peserta didik khususnya agama Hindu, protestan dan Konghucu. Sehingga ada pelajaran agama yang di gabungkan baik di SMAN.1 Sungailiat, SMA Setia Budi dan SMAN.1 Belinyu. Jadi, jika pelajaran agama berlangsung peserta didik yang beragama Konghucu diberikan kebebasan untuk mengikuti materi pelajaran agama lain. Pelajaran agama mana nantinya yang akan diikuti dalam proses pembelajaran. Maka dalam pelaksanaannya sebagian dari mereka ada yang mengikuti materi pelajaran agama Islam dan sebagian agama Budha. Sehingga dalam proses pelaksanaan ada beberapa pelajaran agama yang diberikan tidak sesuai dengan kelompok agamanya peserta didik. Namun, untuk di SMA Setia Budi, bagi peserta didik yang tidak memiliki kelas pendidikan agama sesuai dengan agama yang dianutnya, pihak sekolah terlebih dahulu melakukan koordinasi kepada orang tua. 
Pengembangan Kurikulum Pendidikan Agama dalam Menciptakan Sikap Toleransi Beragama di Madrasah Aliyah dan Sekolah Menegah Atas Kabupaten Bangka

Dalam proses pembelajaran, semua guru agama yang di dalamnya terdapat peserta didik beragama lain mereka sepakat bahwa, penyampaian materi diberikan sesuai dengan pedoman yang berlaku tanpa mempengaruhi atau merubah keyakinan mereka materi pendidikan agama tertentu tidak sesuai dengan agama yanng dianut peserta didik. Kondisi ini sudah sering disampaikan kepada pihak terkait, namun belum bisa direalisasikan dengan baik.

Menuru Siti Maryani, ${ }^{27}$ banyak peserta didik beragam Konghucu mengikuti pelajaran agama Islam. Dalam proses pelaksanaan pembelajaran peserta didik yang beragama selain Islam, sangat antusias mendengarkan penjelasan materi, bahkan mereka sangat aktif memberikan pertanyaan-pertanyan terkait dengan materi yang sudah disampaikan. Namun, ada hal yang sangat sulit dijelaskan ketika mereka bertanya tentang konsep setelah kematian. Dalam Islam, jelas disebutkan antara dosa, pahala, halal, haram, sorga dan neraka. Sedangkan mereka yang beragama Konghucu sulit untuk menjelaskan, karena mereka sendiri tidak memahami apa kitab suci yang mereka pegang. Jadi, dalam realisasi ibadah sehari-hari mereka melaksanakan berupa ritual/tradisi yang sudah dilaksanakan turun temurun.

Berkaitan dengan fasilitas keagamaan di SMAN.1 Sungailiat dan Belinyu masingmasing memiliki masjid, sedangkan untuk agama lain menurut Ferdiro, Dimanik dan Sumarni, ${ }^{28}$ guru langsung mengajak ke tempat peribadatan yang dekat dengan sekolah. Hal ini disebabkan karena pelaksanaan keagamaan selain Islam hanya dilakukan pada waktu-waktu tertentu dan tidak bertepatan dengan jam pelajaran. Sedangkan SMA Setia Budi selain memiliki masjid, mereka juga memfasilitasi ruang ibadah Budha dan Kristen dengan menggunakan Gedung Aula.Sehingga dapat disimpulkan bahwa, pelaksanaan pendidikan agama di ketiga sekolah tersebut belum bisa dilaksanakan sesuai dengan agama peserta didik masing-masing. Karena keterbatasan kelas dan belum tersedia guru agama tertentu seperti Kristen Protestan, Hindu dan Konghucu

\footnotetext{
${ }^{27}$ Siti Maryani, Guru Pendidikan Agama Islam SMA.Negeri 1 Sungailiat.

${ }^{28}$ Ferdiro, Dimanik guru Agama Kristen, Sumarni guru agama Budha SMA N.1 Sungailiat.
} 


\section{Materi Pendidikan Agama di Sekolah Menengah Atas Tentang Toleransi Beragama}

Materi agama di Sekolah Menengah Atas yang menjadi lokasi penelitian baik di SMAN. 1 Sungailliat, SMA Setia Budi Sungailiat dan SMAN.1 Belinyu semuanya sama, menggunakan buku pegangan dari Kemendiknas 2018. Sehingga dalam pembahasan ini, akan menyampaikan materi pendidikan agama terkait dengan pembahasan toleransi yang termuat dalam Kompetensi Inti dan Kompetensi Dasar baik secara tersurat maupun tersirat.

a. Materi Pendidikan Agama Islam

Buku pendidikan Agama Islam dan Budi Pekerti di SMA dari Kemendikbud tahun 2018 yang digunakan, dengan Peraturan Menteri Pendidikan dan Kebudayaan Nomor 37 Tahun 2018 Tentang Perubahan Atas Peraturan Menteri Pendidikan dan Kebudayaan Nomor 24 Tahun 2016 tentang Kompetensi Inti dan Kompetensi Dasar Pelajaran pada Kurikulum 2013 Pada Pendidikan Dasar dan Pendidikan Menengah. Di kelas X, belum menjelaskan secara khusus tentang toleransi namun, makna toleransi dijelaskan dalam Kompetensi Inti 1 (Sikap Spiritual) dan Kompetensi Inti 2 (Sikap Sosial), sebagaimana tabel di bawah ini:

Tabel 1.

Materi Kelas X

\begin{tabular}{cc}
\hline Kompetensi Inti 1 (Sikap Spiritual) & Kompetensi Inti 2 (Sikap Sosial) \\
\hline 1. Menghayati dan mengamalkan & 2. Menunjukkan perilaku jujur, disiplin, bertanggung \\
ajaran agama yang dianutnya & jawab, peduli (gotong royong, kerja sama,toleran, \\
& damai), santun, responsif, dan pro- aktif sebagai \\
& bagian dari solusi atas berbagai permasalahan dalam \\
& berinteraksi secara efektif dengan lingkungan sosial \\
& dan alam serta menempatkan diri sebagai cerminan \\
& bangsa dalam pergaulan dunia \\
&
\end{tabular}

Sedangkan di kelas XI secara detail materi tentang toleransi disampaikan sebagai tabel di bawah ini: 
Pengembangan Kurikulum Pendidikan Agama dalam Menciptakan Sikap Toleransi Beragama di Madrasah Aliyah dan Sekolah Menegah Atas Kabupaten Bangka

Tabel 2.

Materi Kelas XI

\begin{tabular}{|c|c|}
\hline Kompetensi Inti 1 (Sikeap Spiritual) & Kompetensi Inti 2 (Sikeap Sosial) \\
\hline $\begin{array}{l}\text { 1. Menghayati dan mengamalkan } \\
\text { ajaran agama yang dianutnya }\end{array}$ & $\begin{array}{l}\text { 2. Menunjukkan perilaku jujur, disiplin, bertanggung } \\
\text { jawab, peduli (gotong royong, kerja sama, toleran, } \\
\text { damai), santun, responsif, dan pro-aktif sebagai } \\
\text { bagian dari solusi atas berbagai permasalahan } \\
\text { dalam berinteraksi secara efektif dengan } \\
\text { lingkungan sosial dan alam serta menempatkan } \\
\text { diri sebagai cerminan bangsa dalam pergaulan } \\
\text { dunia }\end{array}$ \\
\hline Kompetensi Dasar & Kompetensi Dasar \\
\hline $\begin{array}{l}\text { 1.2 Meyakini bahwa agama } \\
\text { mengajarkan toleransi, } \\
\text { kerukunan, dan menghindarkan } \\
\text { diri dari tindak kekerasan }\end{array}$ & $\begin{array}{l}\text { 2.2 Bersikap toleran, rukun, dan menghindarkan diri } \\
\text { dari tindak kekerasan sebagai implementasi } \\
\text { pemahaman Q.S. Yunus } / 10: 40-41 \text { dan Q.S. al- } \\
\text { Maidab/5:32, serta Hadis terkait }\end{array}$ \\
\hline $\begin{array}{l}\text { 1.2 Menganalisis makna } \\
\text { Q.S.Yunus/10: 40-41 dan Q.S. al- } \\
\text { Maidah/5:32, serta Hadis } \\
\text { tentang toleransi, rukun, dan } \\
\text { menghindarkan diri dari tindak } \\
\text { kekerasan }\end{array}$ & $\begin{array}{l}\text { 2.2 Menyajikan keterkaitan antara kerukunan dan } \\
\text { toleransi sesuai pesan Q.S. Yunus/10:40-41 } \\
\text { dengan menghindari tindak kekerasan sesuai } \\
\text { pesan Q.S. Al-Maidab/5:32 }\end{array}$ \\
\hline
\end{tabular}

Adapun materi di kelas XII secara tersirat menggambarkan tentang makna toleransi, tinggal para guru bisa berekplorasi dalam mengembangkan materi yang ada. Materi tersebut dapat dilihat pada tabel di bawah ini:

Tabel 3.

Materi Kelas XII

\begin{tabular}{lll}
\hline Kompetensi Inti 1 (Sikap Spiritual) & \multicolumn{1}{c}{ Kompetensi Inti 2 (Sikap Sosial) } \\
\hline $\begin{array}{l}\text { Menghayati dan mengamalkan } \\
\text { ajaran agama yang dianutnya }\end{array}$ & 2. & $\begin{array}{l}\text { Menunjukkan perilaku jujur, disiplin, bertanggung } \\
\text { jawab, peduli (gotong royong, kerja sama, toleran, }\end{array}$ \\
& damai), santun, responsif, dan pro- aktif sebagai \\
& bagian dari solusi atas berbagai permasalahan dalam \\
& berinteraksi secara efektif dengan lingkungan sosial \\
& dan alam serta menempatkan diri sebagai cerminan \\
& bangsa dalam pergaulan dunia
\end{tabular}

\begin{tabular}{cc}
\hline Kompetensi Dasar & Kompetensi Dasar \\
\hline $\begin{array}{c}\text { 1.9 Meyakini kebenaran bahwa } \\
\text { dakwah dengan cara damai, }\end{array}$ & $\begin{array}{c}\text { 2.9 } \begin{array}{c}\text { Menjunjung tinggi kerukunan dan kedamaian } \\
\text { dalam kehidupan sehari-hari }\end{array} \\
\text { dilndonesia }\end{array}$ \\
$\begin{array}{c}\text { 1.10 } \begin{array}{l}\text { Meyakini bahwa Islam adalah } \\
\text { rabmatan lil-álamin yang dapat } \\
\text { memajukan peradaban dunia }\end{array} \\
\text { 2.10 Menjunjung tinggi nilai-nilai Islam rabmatanlil-alamin } \\
\text { sebagai pemicu kemajuan peradaban Islam di masa } \\
\text { mendatang }\end{array}$ \\
\hline
\end{tabular}


3.1 Menganalisis dan mengevaluasi makna Q.S. Ali Imran/3:190-191, dan Q.S. Ali Imran/3: 159, serta Hadis tentang berpikir kritis dan bersikap demokratis

3.2 Menganalisis dan mengevaluasi makna Q.S. Luqman/31:13-14 dan Q.S. al-Baqarah/2: 83, serta Hadis tentang kewajiban beribadah dan bersyukur kepada Allah serta berbuat baik kepada sesama manusia
4.1.3 Menyajikan keterkaitan antara sikap kritis dengan ciri orang-orang berakal (ulil albab) sesuai pesan Q.S. Ali Imran/3: 190-191

4.1.4Menyajikan keterkaitan antara kewajiban beribadah dan bersyukur kepada Allah dengan berbuat baik terhadap sesama manusia sesuai pesan Q.S. Luqman/31: 13-14 dan Q.S. al-Baqarah/2:83

\section{b. Materi Pendidikan Agama Buddha}

Seluruh KD Pelajaran Pendidikan Agama Buddha dan Budi Pekerti Kelas X.XI dan XII diorganisasikan ke dalam empat Kompetensi Inti (KI). KI 1 berkaitan dengan sikap diri terhadap Tuhan Yang Maha Esa. KI 2 berkaitan dengan karakter diri dan sikap sosial. KI 3 berisi KD tentang pengetahuan terhadap materi ajar, sedangkan $\mathrm{KI} 4$ berisi $\mathrm{KD}$ tentang penyajian pengetahuan. $\mathrm{KI}$ 1, KI 2, dan KI 4 harus dikembangkan dan ditumbuhkan melalui proses pembelajaran setiap materi pokok yang tercantum dalam KI 3. KI 1 dan KI 2 tidak diajarkan langsung (direct teaching), tetapi indirect teaching pada setiap kegiatan pembelajaran. Materi tentang toleransi, secara khusus tidak disebutkan dalam materi pembelajaran baik di kelas X, XI, dan XII. Namun secara tersirat ada beberapa materi yang memuat didalamnya mengandung makna toleransi. Adapun materi tersebut bisa dilihat pada tabel di bawah ini:

Tabel 4.

Materi Kelas X

\begin{tabular}{crl}
\hline Kompetensi Inti 1 (Sikap Spiritual) & \multicolumn{1}{c}{ Kompetensi Inti 2 (Sikap Sosial) } \\
\hline $\begin{array}{ll}\text { Menghayati dan mengamalkan } \\
\text { ajaran agama yang dianutnya }\end{array}$ & 2. & $\begin{array}{l}\text { Menunjukkan perilaku jujur, disiplin, bertanggung } \\
\text { jawab, peduli (gotong royong, kerja sama, toleran, }\end{array}$ \\
damai), santun, responsif, dan pro-aktif sebagai \\
bagian dari solusi atas berbagai permasalahan \\
dalam berinteraksi secara efektif dengan lingkungan \\
sosial dan alam serta menempatkan diri sebagai \\
cerminan bangsa dalam pergaulan dunia
\end{tabular}


Pengembangan Kurikulum Pendidikan Agama dalam Menciptakan Sikap Toleransi Beragama di Madrasah Aliyah dan Sekolah Menegah Atas Kabupaten Bangka

\begin{tabular}{|c|c|c|}
\hline $\begin{array}{l}\text { 3.2 Memahami peranan agama, tujuan } \\
\text { hidup, dan perlindungan } \\
\text { berdasarkan agama Buddha }\end{array}$ & \multicolumn{2}{|c|}{$\begin{array}{l}\text { 4.2 Menyaji peranan agama, tujuan hidup, dan } \\
\text { perlindungan berdasarkan agama Buddha }\end{array}$} \\
\hline \multicolumn{3}{|c|}{$\begin{array}{l}\text { Tabel } 5 . \\
\text { Materi Kelas XI }\end{array}$} \\
\hline Kompetensi Inti 1 (Sikap Spiritual) & & Kompetensi Inti 2 (Sikap Sosial) \\
\hline $\begin{array}{l}\text { 1. Menghayati dan mengamalkan } \\
\text { ajaran agama yang dianutnya }\end{array}$ & 2. & $\begin{array}{l}\text { Menunjukkan perilaku jujur, disiplin, } \\
\text { bertanggung jawab, peduli (gotong royong, kerja } \\
\text { sama, toleran, damai), santun, responsif, dan pro- } \\
\text { aktif sebagai bagian dari solusi atas berbagai } \\
\text { permasalahan dalam berinteraksi secara efektif } \\
\text { dengan lingkungan sosial dan alam serta } \\
\text { menempatkan diri sebagai cerminan bangsa } \\
\text { dalam pergaulan dunia }\end{array}$ \\
\hline Kompetensi Dasar & & Kompetensi Dasar \\
\hline $\begin{array}{l}\text { 1.1 Mengamalkan aspek-aspek dan } \\
\text { pengklasifikasian sila }\end{array}$ & 2.1 & $\begin{array}{l}\text { Menunjukkan perilaku disiplin dan bertanggung } \\
\text { jawab tentang aspek- aspek dan } \\
\text { pengklasifikasian sila }\end{array}$ \\
\hline $\begin{array}{l}\text { 1.2 Menghayati puja terkait dengan } \\
\text { budaya }\end{array}$ & 2.2 & $\begin{array}{l}\text { Menunjukkan perilaku santun, responsif dan } \\
\text { proaktif terkait puja dengan budaya }\end{array}$ \\
\hline
\end{tabular}

Tabel 6.

Materi Kelas XII

\begin{tabular}{|c|c|}
\hline Kompetensi Inti 1 (Sikeap Spiritual) & Kompetensi Inti 2 (Sikeap Sosial) \\
\hline $\begin{array}{l}\text { 1. Menghayati dan mengamalkan } \\
\text { ajaran agama yang dianutnya }\end{array}$ & $\begin{array}{l}\text { 2. Menunjukkan perilaku jujur, disiplin, bertanggung } \\
\text { jawab, peduli (gotong royong, kerja sama, toleran, } \\
\text { damai), santun, responsif, dan pro-aktif sebagai } \\
\text { bagian dari solusi atas berbagai permasalahan } \\
\text { dalam berinteraksi secara efektif dengan } \\
\text { lingkungan sosial dan alam serta menempatkan } \\
\text { diri sebagai cerminan bangsa dalam pergaulan } \\
\text { dunia }\end{array}$ \\
\hline Kompetensi Dasar & Kompetensi Dasar \\
\hline $\begin{array}{l}\text { 3.3 Menganalisis pengetahuan } \\
\text { tentang masalah-masalah } \\
\text { sosial ditinjau dari agama } \\
\text { Buddha }\end{array}$ & $\begin{array}{l}\text { Menalar masalah-masalah sosial di tinjau dari } \\
\text { agama Buddha }\end{array}$ \\
\hline
\end{tabular}

c. Materi Pendidikan Agama Kristen

Materi pendidikan agama Kristen sesuai dengan tujuan dan ruang lingkup pembahaan, maka akan terlihat dari Kompetensi Dasar dari masing-masing materi terutama tentang baik tersirat maupun tersurat. Untuk materi tersebut dapat dilihat pada tabel di bawah ini. 
Tabel 7.

Materi Kelas X

\begin{tabular}{|c|c|}
\hline Kompetensi Inti (Sikap Spiritual) & Kompetensi Inti (Sikap Sosial) \\
\hline $\begin{array}{l}\text { 1. Menghayati dan mengamalkan } \\
\text { ajaran agama yang dianutnya. }\end{array}$ & $\begin{array}{l}\text { 2. Menunjukkan perilaku jujur, disiplin, bertanggung } \\
\text { jawab, peduli (gotong royong, kerja sama, toleran, } \\
\text { damai), santun, responsif, dan pro- aktif sebagai } \\
\text { bagian dari solusi atas berbagai permasalahan } \\
\text { dalam berinteraksi secara efektif dengan } \\
\text { lingkungan sosial dan alam serta menempatkan } \\
\text { diri sebagai cerminan bangsa dalam pergaulan } \\
\text { dunia }\end{array}$ \\
\hline
\end{tabular}

\begin{tabular}{cc}
\hline Kompetensi Dasar & Kompetensi Dasar \\
\hline 1.2 Menghayati nilai-nilai Kristiani: & 2.2 Meneladani Yesus dalam mewujudkan nilai-nilai \\
kesetiaan, kasih dan keadilan & Kristiani: kesetiaan, kasih dan keadilan dalam \\
dalam kehidupan sosial & kehidupan sosial \\
1.3 Mengakui peran Roh Kudus & Bersedia hidup baru sebagai wujud percaya pada \\
dalam membaharui kehidupan & peran Roh Kudus sebagai pembaharu \\
orang beriman & \\
1.4 Mensyukuri karunia Allah & \\
melalui kebersamaan dengan & 2.4 Bersedia hidup bersama dengan orang lain tanpa \\
orang lain tanpa kehilangan & kehilangan identitas \\
identitas & \\
1.5 Mensyukuri keberadaan Allah & \\
sebagai pembaharu kehidupan & \\
manusia dan alam & Merespons keberadaan Allah sebagai pembaharu \\
\end{tabular}

Tabel 8.

Materi Kelas XI

\begin{tabular}{|c|c|}
\hline Kompetensi Inti 1 (Sikap Spiritual) & Kompetensi Inti 2 (Sikap Sosial) \\
\hline $\begin{array}{l}\text { 1. Menghayati dan mengamalkan } \\
\text { ajaran agama yang dianutnya }\end{array}$ & $\begin{array}{l}\text { 2. Menunjukkan perilaku jujur, disiplin, bertanggung } \\
\text { jawab, peduli (gotong royong, kerja sama, toleran, } \\
\text { damai), santun, responsif, dan pro- aktif sebagai } \\
\text { bagian dari solusi atas berbagai permasalahan } \\
\text { dalam berinteraksi secara efektif dengan } \\
\text { lingkungan sosial dan alam serta menempatkan } \\
\text { diri sebagai cerminan bangsa dalam pergaulan } \\
\text { dunia }\end{array}$ \\
\hline Kompetensi Dasar & Kompetensi Dasar \\
\hline $\begin{array}{l}\text { 1.5 Mengakui bahwa perkembangan } \\
\text { kebudayaan, ilmu pengetahuan, } \\
\text { seni, dan teknologi adalah } \\
\text { anugerah Allah }\end{array}$ & $\begin{array}{l}\text { 2.5 Bersikap kritis dalam menyikapi perkembangan } \\
\text { kebudayaan, ilmu pengetahuan, seni, dan } \\
\text { tekonologi dengan mengacu pada Alkitab }\end{array}$ \\
\hline
\end{tabular}


Pengembangan Kurikulum Pendidikan Agama dalam Menciptakan Sikap Toleransi Beragama di Madrasah Aliyah dan Sekolah Menegah Atas Kabupaten Bangka

Tabel 9.

Materi Kelas XII

\begin{tabular}{|c|c|}
\hline Kompetensi Inti 1 (Sikap Spiritual) & Kompetensi Inti 1 (Sikap Sosial) \\
\hline 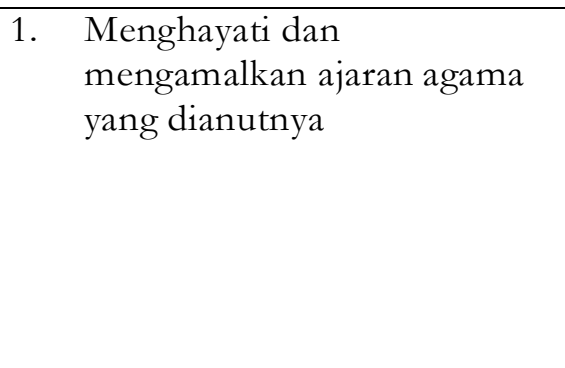 & $\begin{array}{l}\text { 2. Menunjukkan perilaku jujur, disiplin, } \\
\text { bertanggung jawab, peduli (gotong royong, } \\
\text { kerja sama, toleran, damai), santun, responsif, } \\
\text { dan pro- aktif sebagai bagian dari solusi atas } \\
\text { berbagai permasalahan dalam berinteraksi } \\
\text { secara efektif dengan lingkungan sosial dan } \\
\text { alam serta menempatkan diri sebagai cerminan } \\
\text { bangsa dalam pergaulan dunia }\end{array}$ \\
\hline Kompetensi Dasar & Kompetensi Dasar \\
\hline $\begin{array}{l}\text { 1.1 Menerima demokrasi dan } \\
\text { HAM sebagai anugerah Allah }\end{array}$ & $\begin{array}{l}\text { 2.1 Mengembangkan perilaku yang mencerminkan } \\
\text { nilai-nilai demokrasi dan HAM }\end{array}$ \\
\hline $\begin{array}{l}\text { 1.2 Mensyukuri pemberian Allah } \\
\text { dalam kehidupan multikultur }\end{array}$ & $\begin{array}{l}\text { 2.2 Mengembangkan sikap dan perilaku yang } \\
\text { menghargai dan menerima multikultur }\end{array}$ \\
\hline $\begin{array}{l}\text { 1.3 Menghayati pentingnya } \\
\text { keadilan sebagai dasar } \\
\text { mewujudkan demokrasi dan } \\
\text { HAM mengacu pada Alkitab }\end{array}$ & $\begin{array}{l}\text { 2.3 Mengembangkan rasa keadilan sebagai dasar } \\
\text { mewujudkan demokrasi dan HAM mengacu } \\
\text { pada Alkitab }\end{array}$ \\
\hline $\begin{array}{l}\text { 1.4 Menghayati dan menjalankan } \\
\text { perannya sebagai pembawa } \\
\text { damai sejahtera dalam } \\
\text { kehidupan sehari- hari }\end{array}$ & $\begin{array}{l}\text { 2.4 Bersikap pro-aktif sebagai pembawa damai } \\
\text { sejahtera dalam kehidupan sehari-hari }\end{array}$ \\
\hline
\end{tabular}

\section{Sikap Toleransi Beragama di Sekolah Menengah Atas}

Memiliki peserta didik yang bermacam-macam agama, suku, dan budaya, memberikan nuansa yang berbeda dalam berinteraksi di lingkungan sekolah. Berdasarkan hasil wawancara dengan informan memberikan penjelasan yang sama tentang toleransi beragama. Adapun indikator dari toleransi adanya saling menghargai, menghormati perbedaan agama lain, tanpa menjelekkan dan paksaan antara satu dengan yang lainnya. Jadi sikap toleransi beragama adalah sebuah sikap saling menghargai, menghormati dan memahami perbedaan agama masing-masing.

Berdasarkan hasil observasi dan wawancara yang telah dilakukan bahwa, pelaksanaan toleransi beragama di SMA Negeri 1 Sungailiat, sudah berjalan dengan baik. Hal ini diihat, dari harmonisasi di lingkungan sekolah, seluruh peserta didik tidak memilih sahabat dalam berinteraksi. Lingkungan sekolahpun sangat mendukung, dengan ditampilkannya slogan-slogan tentang kedamaian antara lain dengan kalimat "Damai Itu Indah" yang berada di halaman sekolah. 
Sikap toleransi beragama di SMA Negeri 1 Belinyu diawali dengan kebijakan sekolah. Melalui misi sekolah yang ke dua yaitu "Mengembangkan budaya gemar membaca, rasa ingin tahu, bertoleransi, bekerja sama, saling menghargai. Menurut Surandi, Toleransi beragama akan berjalan dengan baik apabila diaplikasikan dengan nilai-nilai pancasila bukan dengan agama. Dengan kebijakan yang dilakukan dan penyampaian materi agama dengan baik maka sikap toleransi beragama di SMAN 1 Belinyu berjalan dengan baik dan dinamis.

SMA Setia Budi Sungailiat, merupakan salah satu SMA swasta yang populer ditahun 1975 dengan sebutan SMA Pan Yan. Sebutan Pan Yan sangat identik dengan kepala sekolah SMA yang memimpin ketika itu Sofyan Ilazim. Keberagaman beragaman di SMS Setia Budi ini sangat kental sekali. Karena peserta didiknya memiliki keberagaman agama, etnis yang banyak. Sikap toleransi beragama di SMA Setia Budi dimulai dengan visi yang dikembangnkan yaitu: "Mewujudkan sekolah yang berbudaya lingkungan yanng mampu menghasilkan keluaran berwawasan global, berbudaya bangsa dan semangat kebangsaan dan model sekolah multikultural. Serta di buat slogan "Kawasan Toleransi Beragama".

Untuk mendukung penguatan dan pemahaman berkaiatan dengan toleransi beragama, maka SMA Setia Budi melakukan pengintegrasian wawasan kebangsaan ke dalam kurikulum. Berdasarkan analisa yang telah dilakukan, terkait dengan program khusus yang dibuat dalam rangka pelaksanaan pendidikan multikultural, selama ini tidak ada program khusus yang dibuat. Akan tetapi, pelaksanaan dari pendidikan multikultural di SMA Setia Budi Sungailiat sudah terintegrasi dalam mata pelajaran tertentu antara lain pendidikan agama, Sosiologi, PKN, dan Sejarah yang tergambar dalam RPP sedangkan dalam teknis pembelajarannya diserahkan kepada guru masingmasing. Selanjutnya dalam proses pembelajaran khususnya mata pelajaran agama, dilakukan dengan sistem moving class yaitu: agama Islam, Kristen, Budha, dan Katolik.

Dalam membangun pendidikan multikultural di SMA Setia Budi Sungailiat, dikonsep dalam wawasan kebangsaan dengan membuat dan melaksanakan kegiatan ekstrakurikuler yang melibatkan seluruh siswa tanpa membedakan latar belakang agama,suku dan etnis. Dalam kegiatan-kegiatan perayaan keagamaan menjadi satu 
Pengembangan Kurikulum Pendidikan Agama dalam Menciptakan Sikap Toleransi Beragama di Madrasah Aliyah dan Sekolah Menegah Atas Kabupaten Bangka

landasan terbentuknya pola sikap menyadari hakikat hidup beragama, toleransi dalam satu pola masyarakat belajar (learning society) yang madani. Hasil dari pola-pola yang telah di bentuk, diharapkan siswa mempunyai karakter kebangsaan, menghargai kemajemukan, toleransi pada masing-masing pemeluk agama dan bangga terhadap negaranya. Pendidikan multikultural yang sudah diterapkan dapat dilaksanakan di dalam maupun di luar kelas dengan memperbanyak kegiatan Ekstrakurikuler.

Berdasarkan analisa dari observasi dan wawancara, indikator dari toleransi beragama adanya saling menghargai, menghormati perbedaan agama lain, dengan tidak menjelekkan dan memaksa antara satu dengan yang lainnya. Adapun sikap toleransi di SMAN 1 Sungailiat, SMA Setia Budi, dan SMAN 1 Belinyu berjalan dengan baik dan dinamis. Dilihat dari model toleransi yang telah dilakukan di tiga SMA tersebut, terjalin toleransi aktif dan dinamis sesama dan antar agama di lingkungan sekolah.

\section{F. Pengembangan Kurikulum Pendidikan Agama dalam Menciptakan Sikap Toleransi Beragama Di Madrasah Aliyah Kabupaten Bangka \\ 1. Pengembangan Kurikulum di Madrasah Aliyah}

Berdasarkan analisa dari hasil wawancara bahwa pengembangan Kurikulum sebuah proses upaya peningkatan kualitas pendidikan sesuai dengan era sekarang. Oleh sebab itu, pengembangan kurikulum sangat perlu untuk dilakukan. Karena, kurikulum merupakan salah satu acuan, pedoman dalam mengembangkan pembelajaran di kelas. Sebagai pedoman bagaimana seorang pendidik memberi warna atau corak dalam hasil pembelajaran. Untuk menunjang proses itu, sekolah berusaha untuk memberi peluang kepada guru untuk mengikuti berbagai pelatihan-pelatihan di luar, kegiatan di MGMP, MKKS dan kegiatan-kegiatan yang dilakukan di pusat. Adapun untuk mengikuti kegiatan baik yang dilakukan pusat maupun daerah, diberikan kesempatan kepada semua guru sesuai dengan bidang studi yang diajarkan masing-masing. Seandainya undangan tersebut diperuntukkan bagi guru PAI yang pernah mengikuti, maka pihak sekolah menggantikan kepada guru mana yang belum pernah mengikuti pelatihat tersebut. Sehingga harapannya, semua guru bisa 
mengikutinya. Dengan kondisi sekarang, kurikulum yang digunakan adalah K.13 bukan suatu hal yang sulit bagi guru untuk mengaplikasikan pengembanngan kurikulum. Namun, kadang-kadang keterbatasan sarana dan prasarana yang dirasakan oleh pihak madrasah terlebih madrasah swasta, menjadi suatu hambatan untuk melakukannya.

\section{Pelaksanaan Pendidikan Agama di Madrasah Aliyah}

Pelaksanaan pendidikan agama terkait dengan materi aqidah akhlak dan qur'an hadist, hanya melihat di jurusan Pendidikan Agama Islam (PAI) saja. Di MAN 1 Sungailiat pelaksanan kedua mata pelajaran tersebut diberikan oleh guru sesuai dengan bidang oilihannya. Namun, untuk MA Petaling dan Nurul Falah Pangkal Niur, diberikan oleh guru yang sama dikarenakan keterbatasan guru.

\section{Materi Pendidikan Agama di Madrash Aliyah}

Berkenaan dengan materi agama di madrasah sangat banyak, maka dalam penelitian ini hanya mengambil dua mata pelajaran yang sangat erat hubungan dengan tema toleransi yaitu Qur'an Hadis dan Aqidah akhlah.

Tabel 10.

Materi Qur'an Hadist Madrasah Aliyah Kelas X Semester Gasal

\begin{tabular}{|c|c|}
\hline Kompetensi Inti & Kompetensi Dasar \\
\hline $\begin{array}{l}\text { 1. Menghayati dan mengamalkan ajaran } \\
\text { agama yang dianutnya }\end{array}$ & $\begin{array}{l}\text { 1.1. Menghayati keautentikan Al-Qur'an sebagai wahyu } \\
\text { Allah } \\
\text { 1.2. Meyakini Al-Qur'an sebagai pedoman hidup } \\
\text { 1.3. Memfungsikan Al-Qur'an secara tepat dan benar dalam } \\
\text { kehidupan sehari-hari } \\
\text { 1.4. Meyakini kebenaran nilai-nilai yang terdapat pada } \\
\text { pokok-pokok isi Al-Qur'an } \\
\text { 1.5. Beramal sesuai dengan kandungan Surah al-Nahl:78 }\end{array}$ \\
\hline
\end{tabular}

Tabel 11.

Materi Qur'an Hadist Madrasah Aliyah Kelas X Semester Genap

\begin{tabular}{|c|c|}
\hline Kompetensi Inti & Kompetensi Dasar \\
\hline $\begin{array}{l}\text { 1. Menghayati dan mengamalkan perilaku jujur, } \\
\text { disiplin, tanggungjawab, peduli (gotong } \\
\text { royong, kerja sama, toleran, damai) santun, } \\
\text { responsif dan pro-aktif dan menunjukkan } \\
\text { sikap sebagai bagian dari solusi atas berbagai } \\
\text { permasalahan dalam berinteraksi secara efektif } \\
\text { dengan lingkungan sosial dan alam serta dalam } \\
\text { menempatkan diri sebagai cerminan bangsa } \\
\text { dalam pergaulan dunia }\end{array}$ & $\begin{array}{l}\text { 2.1. Menunjukkan sikap kritis dalam mengamalkan } \\
\text { hadis sebagai dasar dalam kehidupan sehari-hari } \\
\text { 2.2. Menunjukkan perilaku yang menggunakan hadis } \\
\text { sebagaimana fungsinya yang telah dipelajari } \\
\text { 2.3. Menunjukkan perilaku yang selektif terhadap } \\
\text { keanekaragaman hadis }\end{array}$ \\
\hline
\end{tabular}


Pengembangan Kurikulum Pendidikan Agama dalam Menciptakan Sikap Toleransi Beragama di Madrasah Aliyah dan Sekolah Menegah Atas Kabupaten Bangka

\section{Tabel 12.}

Materi Qur'an Hadist Madrasah Aliyah Kelas XI Semester Gasal

Kompetensi Inti Kompetensi Dasar

1. Menghayati dan mengamalkan ajaran agama yang dianutnya

2. Menghayati dan mengamalkan perilaku jujur, disiplin, tanggungjawab, peduli (gotong royong, kerjasama, toleran, damai) santun, rensponsif dan pro-aktif dan menunjukkan sikap sebagai bagian dari solusi atas berbagai permasalahan dalam berinteraksi secara efektif dengan lingkungan sosial dan alam serta dalam menempatkan diri sebagai cerminan bangsa dalam pergaulan dunia
1.1. Menghayati nilai-nilai toleransi intern umat beragama dan antar umat beragama

2.1. Menunjukkan perilaku hormat dan patuh kepada orang tua dan guru sebagai implementasi dari pemahaman Surah al-Isra' (17): 23-24; Surah Luqman (31): 13-17; hadis riwayat Muslim dari Abu Hurairah

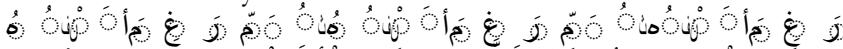

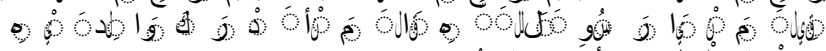

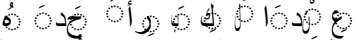

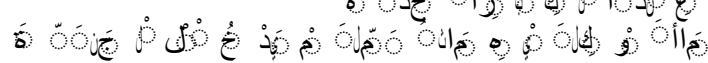
hadis riwayat Al-Bukhari dan Muslim dari Abdullah bin

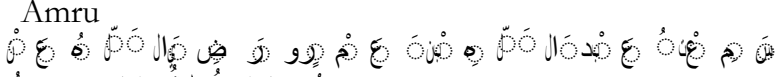

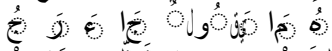

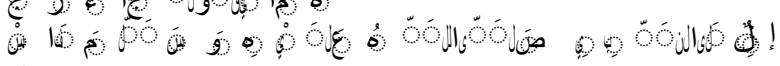

$$
\begin{aligned}
& \Leftrightarrow
\end{aligned}
$$

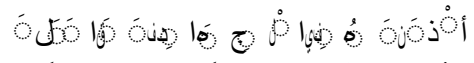

$$
\begin{aligned}
& \text { बिंक्ष }
\end{aligned}
$$

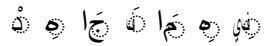

2.2. Menunjukkan perilaku kontrol diri (mujahadah an-nafs), prasangka baik (pusnuzzan), dan persaudaraan (ukhuwah) yang terdapat Surah al-Anfal (8) : 72; Q.S. al-Hujurat (49): 12; Q.S. al-Hujurat (49): 10); serta hadis riwayat AlBukhari dari Abu Hurairah

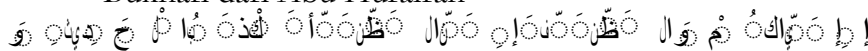

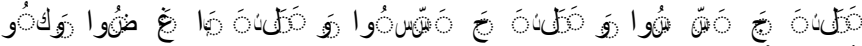

..

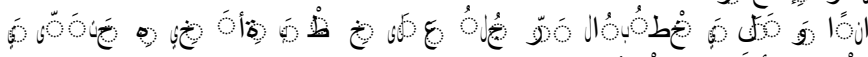
s)

2.3. Memiliki sikap toleransi dan menjunjung tinggi etika pergaulan sebagai implementasi dari pemahaman Surah al-Kafirun: 1-6; Surah Yunus: 40-41; Surah al-Kahfi: 29; Surah al-Hujurat: 10-13 dan hadis riwayat Ahmad dari Ibnu Abbas

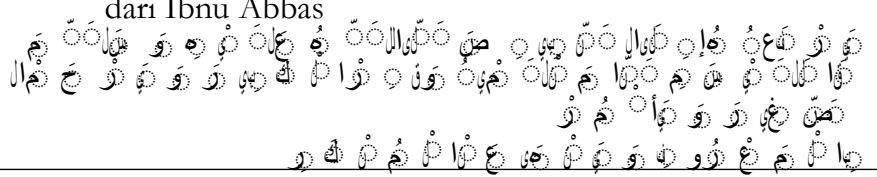

Tabel 13.

Materi Qur'an Hadist Madrasah Aliyah Kelas XI Semester Genap Kompetensi Inti Kompetensi Dasar

1. Menghayati dan mengamalkan ajaran 1.1. Meyadari nilai-nilai tanggung jawab terhadap keluarga agama yang dianutnya

1.2. Menyadari pentingnya nilai-nilai kompetitif dan kerja sama dalam kebaikan 
Pengembangan Kurikulum Pendidikan Agama dalam Menciptakan Sikap Toleransi

2. Mengembangkan perilaku (jujur, disiplin, tanggungjawab, peduli, santun, ramah lingkungan, gotong royong, kerjasama, cinta damai, responsive dan pro-aktif dan menunjukkan sikap sebagai bagian dari solusi atas berbagai permasalahan bangsa dalam berinteraksi secara efektif dengan lingkungan sosial dan alam serta dalam menempatkan diri sebagai cerminan bangsa dalam pergaulan dunia
2.1. Menunjukkan perilaku tanggung jawab manusia terhadap keluarga dan masyarakat sebagai implementasi dari pemahaman Surah at-Tahrim (66): 6, Surah Taha (20): 132, al-An'am (6): 70, an-Nisa'(4) :36, Hud (11):117-119 dan hadis riwayat Al-Bukhari dari Abdullah bin Umar

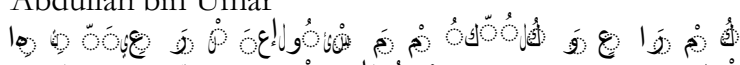

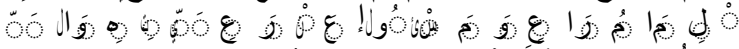
- एँ

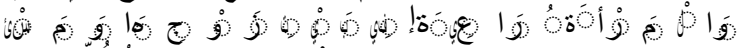

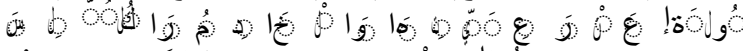

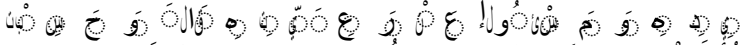

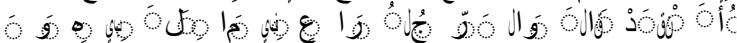
L

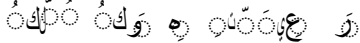
$08 \lg 60 \%$ .0000

H.R. Abu Dawud dari Ar-Rabi' bin Sabrah

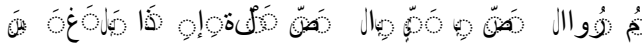

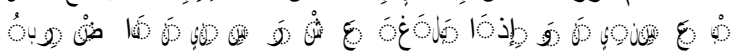
oleh Al-Bukhari dan Muslim dari ló Abu Hurairah dan hadis riwayat

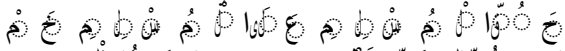

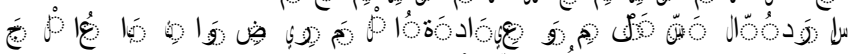
\&

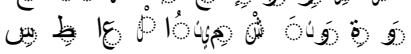

2.2. Membiasakan sikap kompetitif dalam kebaikan sebagai pemahaman atas Surah al-Baqarah :148, Surah al-Fathir 
Soleha

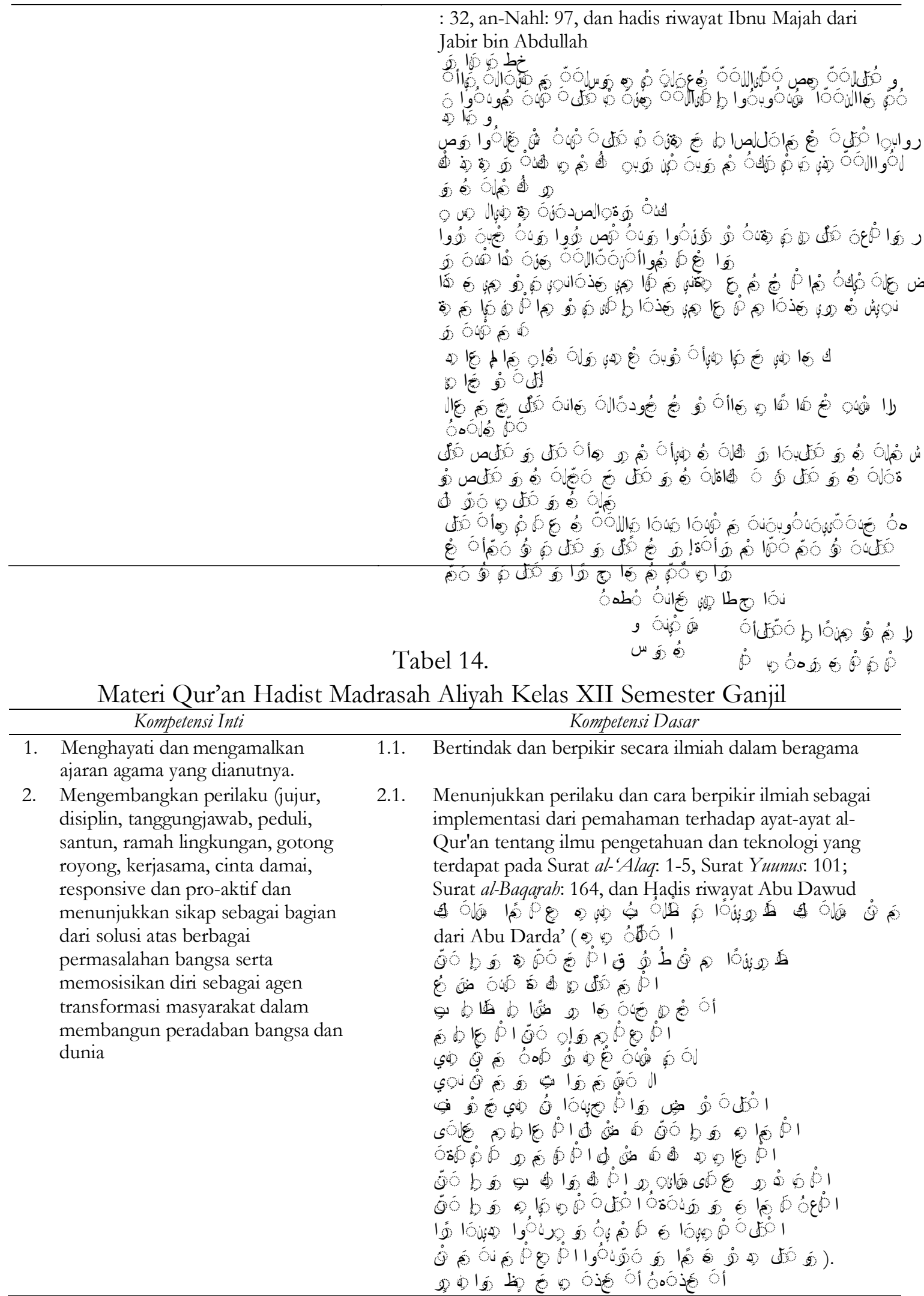

Tabel 15.

Materi Qur'an Hadist Madrasah Aliyah Kelas XII Semester Genap 
Soleha

1. Menghayati dan mengamalkan ajaran agama yang dianutnya.

2. Mengembangkan perilaku (jujur, disiplin, tanggungjawab, peduli, santun, ramah lingkungan, gotong royong, kerjasama, cinta damai, responsive dan pro-aktif dan menunjukkan sikap sebagai bagian dari solusi atas berbagai permasalahan bangsa serta memosisikan diri sebagai agen transformasi masyarakat dalam membangun peradaban bangsa dan dunia.
1.1. Melakukan dakwah dengan hikmah, mau’idhah hasanah dan perdebatan yang baik

1.2. Melakukan amar makruf nahi munkar secara tepat dengan tangan, lisan, dan hati

1.3. Menghayati nilai-nilai demokratis dalam kehidupan sehari-hari

1.4. Menghayati nilai-nilai kejujuran dalam kehidupan seharihari

2.1. Menunjukkan perilaku dalam dakwah yang baik sebagai implementasi dari Surat an-Nabl (16): 125, Surat asySyu'araa (26): 214-216, surah al-Hijr (15): 94-96, dan Hadis riwayat Muslim dari Abu Hurairah ॰

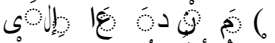

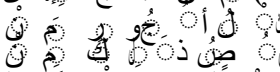

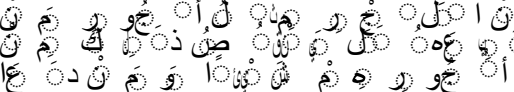

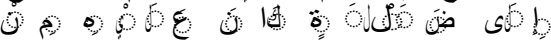

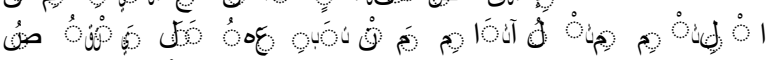

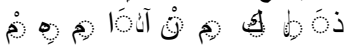

) $\log \theta$

2.2. Menunjukkan perilaku yang mencerminkan kewajiban amar ma'ruf nahi munkar dalam kehidupan sehari-hari sebagaimana sebagai implementasi dari pemahaman atas Surat Ali Imraan: 104, hadis Ibnu Majah dari Qais bin Hazim ( dan hadis Muslim dari Abu

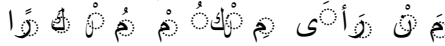

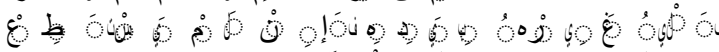

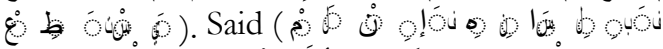

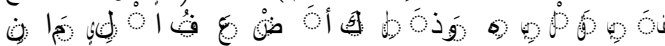

2.3. Memiliki sikap demokratis dalam kehidupan sehari-hari sebagai implementasi dari pemahaman atas Surat $A l i$ 


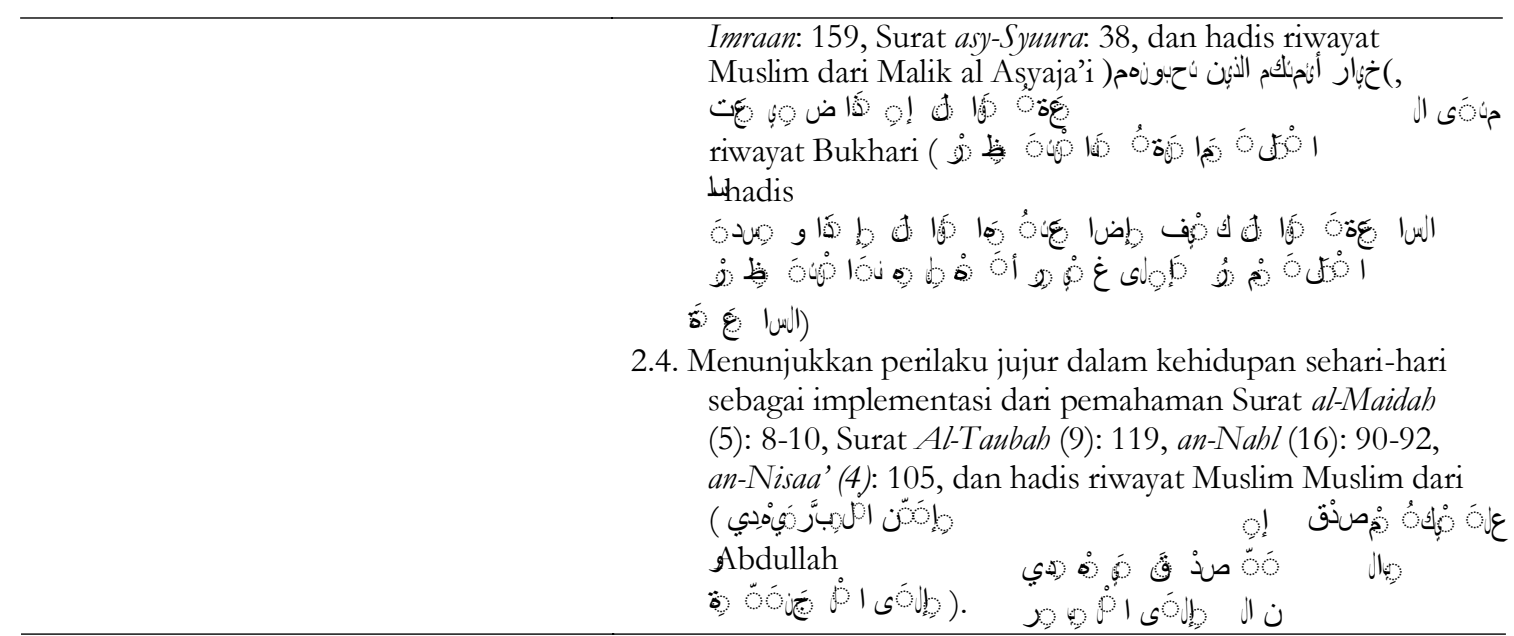

Selain Qur'an hadits, materi aqidah akhlak yang disampaikan dalam buku Ayo Mengkaji Aqidah dan Akhlak 3, karangan Usman dan Ida Inayahwanti penerbit Erlangga yang berbasis Kurikulum 2013. Sedangkan buku pegangan dari kementerian Agama tidak ada. Untuk materi aqidah akhlah di madrasah terkait dengan toleransi baik tersirat dan tersurat dapat dilihat pada tabel di bawah ini:

Tabel 16.

Materi Akidah Akhlak Madrasah Aliyah Kelas X Semester Ganjil

\begin{tabular}{|c|c|c|}
\hline & Kompetensi Inti & Kompetensi Dasar \\
\hline 2. & $\begin{array}{l}\text { Menghayati dan } \\
\text { mengamalkan perilaku jujur, } \\
\text { disiplin, tanggung jawab, } \\
\text { peduli (gotong royong, kerja } \\
\text { sama, toleransi, damai), } \\
\text { santun, responsif dan pro- } \\
\text { aktif dan menunjukkan sikap } \\
\text { sebagai bagian dari solusi atas } \\
\text { berbagai permasalahan dalam } \\
\text { berinteraksi secara efektif, } \\
\text { sosial dan alam serta dalam } \\
\text { menempatkan diri sebagai } \\
\text { cerminan bangsa dalam } \\
\text { pergaulan dunia. }\end{array}$ & $\begin{array}{l}\text { 2.1 Memiliki aqidah yang kokoh dalam kehidupan } \\
\text { sehari-hari. } \\
\text { 2.2 Terbiasa bertauhid dalam kehidupan sehari-hari. } \\
\text { 2.3 Terbiasa menerapkan metode-metode peningkatan } \\
\text { kualita akhlak dalam kehidupan. } \\
\text { 2.4 Membiasakan akhlak-akhlak (bikmah, iffah, syaja'ah, } \\
\text { dan 'adalab) dalam kehidupan. } \\
\text { 2.5 Menghindarkan diri dari sifat-sifat buruk (bubbud- } \\
\text { dun-ya, hasad, takabur/ ujub, riya). } \\
\text { 2.7 Terbiasa berakhlak terpuji kepada orang tua dan } \\
\text { guru dalam kehidupan sehari-hari. }\end{array}$ \\
\hline
\end{tabular}

Dilihat dari tabel berkenaan dengan materi yang disampaikan dikelas X bahwa, materi toleransi secara khusus belum disampaikan pada kelas X secara detail. Namun, dalam Kompetensi Inti sedah dijelaskan untuk menghayati dan mengamalkan perilaku toleransi dalam pergaulan di dunia.

\section{Tabel 17.}

Materi Akidah Akhlak Madrasah Aliyah Kelas XI Semester Ganjil

Kompetensi Inti Kompetensi Dasar


Pengembangan Kurikulum Pendidikan Agama dalam Menciptakan Sikap Toleransi

2 Menghayati dan mengamalkan perilaku jujur, disiplin, tanggung jawab, peduli (gotong royong, kerja sama, toleransi, damai), santun, responsif dan pro-
2.1 Terbiasa berpikir kritis dan kreatif serta menghargai keberagaman dalam kehidupan sehari-hari.

2.2 Membiasakan diri untuk menghargai perbedaan aliran-aliran yang ada dalam kehidupan bermasyarakat.

2.3 Menghindari dampak negatif akibat perbuatan dosa 


\begin{tabular}{|c|c|c|}
\hline \multirow{5}{*}{4} & $\begin{array}{l}\text { aktif dan menunjukkan sikap } \\
\text { sebagai bagian dari solusi atas } \\
\text { berbagai permasalahan dalam } \\
\text { berinteraksi secara efektif, } \\
\text { sosial dan alam serta dalam } \\
\text { menempatkan diri sebagai } \\
\text { cerminan bangsa dalam } \\
\text { pergaulan dunia. }\end{array}$ & $\begin{array}{l}\text { besar (mabuk-mabukan, mengkomsumsi narkoba, } \\
\text { berjudi, zina, pergaulan bebas dan mencuri). } \\
\text { 2.4 Membiasakan akhlak (adab) yang baik dalam } \\
\text { berpakaian, berhias, perjalanan, bertamu dan } \\
\text { menerima tamu. }\end{array}$ \\
\hline & $\begin{array}{l}\text { Mengolah, menalar, dan } \\
\text { menyaji dalam ranah } \\
\text { konkrit dan ranah }\end{array}$ & $\begin{array}{l}\text { Menyajikan peta konsep pengertian, ruang lingkup } \\
\text { fungsi ilmu kalam serta hubungannya dengan ilmu } \\
\text { lainnya }\end{array}$ \\
\hline & $\begin{array}{l}\text { abstrak terkait dengan } \\
\text { pengembangan dari yang } \\
\text { dipelajarinya di sekolah } \\
\text { secara mandiri, dan }\end{array}$ & $\begin{array}{l}\text { Menyajikan peta konsep pokok-pokok aliran ilmu } \\
\text { kalam (Khawarij, Murji'ah, Syia'ah, Jabariyah dan } \\
\text { Qodariyah, Assy'ariyah, Al-Maturidiyah dan } \\
\text { Mu'tazilah) }\end{array}$ \\
\hline & $\begin{array}{l}\text { mampu menggunakan } \\
\text { metode sesuai dengan }\end{array}$ & $\begin{array}{l}\text { Menunjukkan contoh perbuatan dosa besar di } \\
\text { masyarakat dan akibatnya. }\end{array}$ \\
\hline & kaidah keilmuan. & $\begin{array}{l}\text { Mensimulasikan akhlak (adab) berpakaian, berhias, } \\
\text { perjalanan, bertamu dan menerima tamu dalam } \\
\text { kehidupan sehari-hari. }\end{array}$ \\
\hline
\end{tabular}

Dilihat dari tabel berkenaan dengan materi yang disampaikan dikelas XI bahwa, bukan hanya disampaikan materi tentang toleransi antar agama, namun secara detail juga dijelaskan tentang toleransi sesama agama.

Tabel 18.

Materi Akidah Akhlak Madrasah Aliyah Kelas XII Semester Ganjil

\begin{tabular}{|c|c|c|}
\hline & Kompetensi Inti & Kompetensi Dasar \\
\hline 2 & $\begin{array}{l}\text { Menghayati dan } \\
\text { mengamalkan perilaku jujur, } \\
\text { disiplin, tanggung jawab, } \\
\text { peduli (gotong royong, kerja } \\
\text { sama, toleransi, damai), } \\
\text { santun, responsif dan pro- } \\
\text { aktif dan menunjukkan sikap } \\
\text { sebagai bagian dari solusi } \\
\text { atas berbagai permasalahan } \\
\text { dalam berinteraksi secara } \\
\text { efektif, sosial dan alam serta } \\
\text { dalam menempatkan diri } \\
\text { sebagai cerminan bangsa } \\
\text { dalam pergaulan dunia. }\end{array}$ & $\begin{array}{l}\text { 2.1 Terbiasa menerapkan nilai-nilai positif yang } \\
\text { terkandung dalam tujuh Asma'ul Husna AL-Gaffar, } \\
\text { Ar-razzaq, Al-Malik, Al-Hasib, Al-Hadi, Al-Khalik } \\
\text { dan Al-Hakim dalam keseharian. } \\
\text { 2.2 Terbiasa berperilaku amal salih, toleransi, musawwah } \\
\text { dan ukhuwah dalam kehidupan sehari-hari. } \\
\text { 2.4 Terbiasa beradab yang baik dalam bergaul dengan } \\
\text { teman sebaya, orang yang lebih tua, oran yang lebih } \\
\text { mudan dan lawan jenis. }\end{array}$ \\
\hline 4 & $\begin{array}{l}\text { Mengolah, menalar, dan } \\
\text { menyaji dalam ranah } \\
\text { konkrit dan ranah abstrak } \\
\text { terkait dengan } \\
\text { pengembangan dari yang } \\
\text { dipelajarinya di sekolah } \\
\text { secara mandiri, dan } \\
\text { mampu menggunakan } \\
\text { metode sesuai dengan } \\
\text { kaidah ilmu pengetahuan. }\end{array}$ & $\begin{array}{l}\text { 4.2 Menyajikan peta konsep tentang keutamaa amal } \\
\text { salih, toleransi, musawwah dan Ukhwah. } \\
\text { Mensimulasikan adab bergaul dengan yang lebih } \\
\text { tua, yang lebih muda dan lawan jenis. }\end{array}$ \\
\hline
\end{tabular}

Tabel 19. 
Pengembangan Kurikulum Pendidikan Agama dalam Menciptakan Sikap Toleransi Beragama di Madrasah Aliyah dan Sekolah Menegah Atas Kabupaten Bangka

Materi Akidah Akhlak Madrasah Aliyah Kelas XII Semester Genap

\begin{tabular}{|c|c|c|c|}
\hline \multicolumn{2}{|r|}{ Kompetensi Inti } & \multicolumn{2}{|r|}{ Kompetensi Dasar } \\
\hline 2 & $\begin{array}{l}\text { Menghayati dan mengamalkan perilaku } \\
\text { jujur, disiplin, tanggung jawab, peduli } \\
\text { (gotong royong, kerja sama, toleransi, } \\
\text { damai), santun, responsif dan pro-aktif dan } \\
\text { menunjukkan sikap sebagai bagian dari } \\
\text { solusi atas berbagai permasalahan dalam } \\
\text { berinteraksi secara efektif, sosial dan alam } \\
\text { serta dalam menempatkan diri sebagai } \\
\text { cerminan bangsa dalam pergaulan dunia. }\end{array}$ & 2.1 & $\begin{array}{l}\text { Membiasakan berperilaku semangat } \\
\text { berkompetisi dalam kebaikan } \\
\text { (fastabiqul khairat), optimis, dinamis, } \\
\text { inovatif dan kreatif. }\end{array}$ \\
\hline
\end{tabular}

\section{Sikap Toleransi Beragama di Madrasah Aliyah}

Sikap toleransi beragama, bukan hanya ditanamkan kepada peserta didik di Sekolah umum saja. Namun. Peserta didik di Madrasah Aliyah pun, harus memiliki sikap toleransi beragama. Karena sikap toleransi harus dimiliki setiap peserta didik dalam berinteraksi di sekolah dan masyarakat,yang disampaikan dalam setiap materi pelajaran terutama materi aqidah akhlak dan qur'an hadist. Sehingga dapat disimpulkan, sikap toleransi sesama agama ketiga Madrasah Aliyah ini terjalin aktif dan dinamis sesama agama dalam lingkungan madrasah.

\section{G. Penutup}

Pengembangan kurikulum pendidikan agama sangat penting dilakukan, karena kondisi zaman semakin berkembang. Sehingga peserta didik dapat memahami akan pentingnya sebuah perbedaan baik dari etis, suku, budaya dam agama. Adapun materi yang sangat erat kaitannya dalam mempelajari akan Sikap toleransi beragama terdapat dalam pendidikan agama di sekolah sedangkan di madrasah mata pelajaran qur'an hadist dan aqidah akhlak.

Adapun sikap toleransi yang berjalan di SMAN 1 Sungailiat, SMAN 1 Belinyu dan SMA Setia Budi berjalan dengan aktif dan dinamis dalam lingkungan sekolah baik sesama agama maupun antar agama. Begitu juga di Madrasah Aliyah Negeri 1 Sungailiat, Madrasah Aliyah Nurul Falah dan Petaling sikap toleransi berjalan dengan aktif dan dinamis. Namun hannya sesama agama saja. 
Soleha

\section{DAFTAR PUSTAKA}

Budhy Munawar dan Rahman, Islam Pluralis “wacana Kesetaraan Kaum Beriman”, Jakarta: PT. Raja Grafindo Persada, 2004.

Departemen Pendidikan Nasional, Kamus Besar Bahasa Indonesia Edisi Keempat, Jakarta: Balai Pustaka.

Efri Rantos, Kepala Sekolah SMAN 1 Sungailiat, wawancara tanggal 2 Agustus jam 08.45 WIB.

Fadhilah Imam, SMA Setia Budi Sungailiat 40 Tahun di tengah Dinamika Pendidikan Nasional, Pangkalpinang: CV. Sumber Sarana Prima 2015.

Fristiana Irina, Pengembangan Kurikulum: Teori, Konsep dan aplikasi, Yokyakarta: Parama Ilmu, 2016.

H. Muhaimin, Pengembangan Kurikulum Pendidikan Agama Islam di Sekolah, Madrasah dan PerguruanTinggi, Jakarta, PT. Raja Grafindo Persada, 2005.

Irwan Abdullah, Konstruksi dan Reproduksi Kebudayaan, Yokyakarta: Pustaka Pelajar, 2009.

Kemendiknas, Bahan pelatihan Penguatan Metodologi Pembelajaran Berdasarkan Nilai-Nilai Budaya untuk. Membentuk Daya Saing dan Karakter Bangsa. Jakarta: Kementrian Pendidikan Nasional Badan Penelitian dan Pengembangan Pusat Kurikulum, 2010.

Kimberly Adams Kimberly \& A.A. Waskito, Kamus Inggris-Indonesia Indonesia-Inggris; Reguler Verb Irreguler Verb, Jakarta: PT. Wahyu Media, 2008.

Lickona, Thomas, Character Matters : Persoalan Karakter, Bagaimana Membantu Anak Mengembangkan Penilaian Yang Baik, Integritas Dan Kebijakan Penting Lainnya, Jakarta : PT. Bumi Aksara, 2015.

https://www.cnnindonesia.com/nasional/20181018153237-20-339600/survei-gurumuslim-punya-opini-intoleran-dan-radikal-tinggi

Maryam, Tesis: Penanaman Sikap Toleransi Siswa dalam Kehidupan Beragama di Sekolah melalui Pendidikan Multikultural (Studi Kasus di SMA Setia Budi Sungailiat Kabupaten Bangka), Program Pascasarjana IAIN Syaikh Abdurrahman Siddik Bangka Belitung, 2018.

Maswardi Muhammad Amin, Pendidikan karakter Anak Bangsa, Jakarta: Baduose Media, 2011.

Nana Syaodhi Sukmadinata, Pengembangan kurikulum, Teori dan Praktik, Bandung: Remaja Rosdakarya, 2000.

Nunu Ahmad dan An-Nahidl dkk, Pendidikan Agama di Indonesia: Gagasan dan Realitas, Jakarta: Puslitbang Pendidikan Agama dan Keagamaan Badan Litbang dan Diklat Kementrian Agama RI, 2010.

Oemar Hamalik, Manajemen Pengembangan Kurikulum, Bandung: Kerjasama Sekolah Pascasarjana Universitas Pendidikan Indonesia dengan PT. Remaja Rosdakarya, cet ke-lima, November 2012.

Sabil Mokodenseho, Toleransi Beragama dan Pembelajaran Agama Islam: Harmoni Masyarakat Minoritas Muslim Manado, Proseding Seminar Nasional dan Temu Ilmiah Jaringan Peneliti IAI Darussalam Blokagung Banyuwangi, https://www.researchgate.net/publication/321866877, diakses tanggal 12-092018. 
Pengembangan Kurikulum Pendidikan Agama dalam Menciptakan Sikap Toleransi Beragama di Madrasah Aliyah dan Sekolah Menegah Atas Kabupaten Bangka

Said Agil Husin Al-Munawar, Fikih Hubungan antar Agama, cet.III, Ciputat: PT Ciputat Press, 2005.

Wawancara dengan Siti Maryani, Guru Pendidikan Agama Islam SMA Negeri 1 Sungailiat.

W.A.Gerungan, Psikologi Sosial, Ed.3, cet.I, Bandung: PT. Refika Aditama, 2004.

Zakiyuddin Baidhawy, Pendidikan Agama Berwawasan Multikultural, Jakarta: PT: Gelora Aksara Pratama, 2005. 